\title{
KONSTRUKSI MODEL MATEMATIKA \\ PENYEBARAN KERUSAKAN (AL-FASAD) DALAM SUATU \\ LINGKUNGAN MUSLIM
}

\author{
Nailul Izzati $^{1 *}$, Silmi Kaaffah ${ }^{2}$ \\ ${ }^{1}$ Fakultas Teknik, Universitas Hasyim Asy'ari \\ ${ }^{2}$ Fakultas Bahasa Arab, International Islamic University of Islamabad \\ Email: nailul.izzatimt@gmail.com
}

\begin{abstract}
Abstrak
Kerusakan demi kerusakan terus terjadi di dunia. Tidak hanya berupa kerusakan alam, tetapi juga kerusakan sosial. Al-Qur'an sebagai petunjuk dan pedoman bagi manusia dalam menjalani kehidupan, telah menyebutkan tentang fenomena kerusakan (al-fasad) yang terjadi. Al-Qur'an telah menyebut secara umum penyebab terjadinya kerusakan, siapa pelakunya, bagaimana pencegahan dan penyembuhnya. Dalam penelitian ini, kerusakan dipandang sebagai suatu penyakit yang dapat menular dan mewabah. Penelitian ini membahas model matematika tentang penyebaran kerusakan akibat interaksi subpopulasi Faasid (sesuatu yang rusak) dengan subpopulasi rentan kerusakan. Model yang dikonstruksi kemudian disimulasikan dengan Metode Runge-Kutta Orde Empat. Hasil simulasi numerik menunjukkan bahwa tingkat kerentanan individu terhadap kerusakan berperan penting dalam penyebaran kerusakan di suatu lingkungan.
\end{abstract}

Kata Kunci: Al-Fasad, Kerusakan, Model Interaksi, Model Matematika, Model Penyakit.

\section{A. Pendahuluan}

Eksploitasi berlebihan terhadap sumber daya alam dalam berbagai bentuk banyak terjadi selama beberapa dekade terakhir. Sebagai contoh, World Wide Fund for Nature (WWF) menyebutkan tentang penangkapan ikan secara berlebihan yang terjadi hampir di seluruh perairan dunia sejak tahun 1970. WWF melaporkan bahwa setengah dari kehidupan laut telah habis dalam jangka waktu 40 tahun. ${ }^{1}$ Penangkapan ikan yang dilakukan secara berlebihan didukung oleh alat tangkap ikan yang cenderung tidak ramah lingkungan dan berdampak pada terumbu karang. Keberlangsungan terumbu karang yang merupakan salah satu habitat ikan, berpengaruh pada populasi ikan yang ada. Sehingga rusaknya terumbu karang dapat mengarah kepada berkurangnya populasi ikan, bahkan mengarah kepada kepunahan.

${ }^{1}$ Jennifer Viegas, "Half of All Marine Life Lost in 40 Years: WWF Report", 10 September 2018, dikutip dari https://www.abc.net.au/news/science/2015-09-16/half-marine-life-lost-in-40years/6779912, diakses tanggal 8 Oktober 2019, 23:15. 
Eksploitasi berlebihan tidak hanya terjadi terhadap sumber daya laut. Pada Agustus 2019, hutan Amazon di Brazil mengalami kebakaran hebat. Kebakaran yang terjadi meningkat $76 \%$ dibandingkan tahun 2018. Kebakaran yang terjadi disinyalir sebagai akibat deforestasi. Hutan hujan ditebang kemudian rantingnya dibiarkan mengering dan dibakar. ${ }^{2}$ Selain Brazil, kebakaran hutan juga terjadi di Indonesia. Pada September 2019, hutan Kalimantan dan Sumatera mengalami kebakaran dahsyat. Menurut World Bank, 28 juta jiwa terdampak oleh kebakaran hutan dan lahan yang terjadi, 19 orang meninggal, dan hampir 500 ribu orang mengalami ISPA. ${ }^{3}$ Kebakaran hutan tidak hanya berdampak secara lokal. Kabut asap yang dihasilkan oleh kebakaran juga menyumbang polusi ke negara tetangga. Kabut asap mengandung karbondioksida yang dapat mencemari udara dan menyebabkan efek rumah kaca. Efek rumah kaca adalah salah satu penyebab pemanasan global dan berdampak buruk pada suhu rata-rata di bumi, ketinggian permukaan air laut, iklim dan cuaca, ekosistem, dan lain-lain.

Dari sini diperoleh gambaran bahwa satu kerusakan dapat mengarah kepada kerusakan yang lain. Rusaknya terumbu karang dan kebakaran hutan hanyalah sebagian contoh kerusakan yang diakibatkan oleh ulah manusia. Perilaku yang menyimpang dari tatanan moral ataupun ajaran agama juga banyak terjadi. Kekerasan, pencurian, perampokan, pembunuhan, penyuapan, penipuan, pergaulan bebas, homoseksual, dan masih banyak lagi.

Dalam Bahasa Arab, kerusakan disebut "al-fasad”. Lafadh fasad disebut sebanyak enam kali dalam Al-Qur'an, salah satunya adalah pada QS Ar-Rum (30): 41, tentang kerusakan yang terjadi di darat dan di laut adalah akibat ulah manusia. Dengan mempertimbangkan al-fasad sebagai penyakit yang dapat menjangkiti individu, bukan tidak mungkin seorang yang terinfeksi al-fasad dapat menularkannya ke individu lain, sehingga tersebarlah al-fasad di muka bumi.

Model matematika tentang penyebaran penyakit pertama kali dikemukakan oleh Kermack \& Mckendrickpada tahun 1927, ${ }^{4}$ yaitu model SIR (SusceptibleInfected-Recovered). Model matematika SIR menggambarkan penularan suatu penyakit akibat interaksi dengan individu terinfeksi. Model SIR terus mengalami perkembangan dan diterapkan dalam berbagai kasus penyebaran penyakit menular, mulai dari influenza, kolera, demam berdarah dengue, malaria, tuberkulosis, HIV/AIDS, dan lain sebagainya. Model matematika penyebaran penyakit secara langsung maupun tidak langsung, membantu penelitian di bidang medis dalam

\footnotetext{
${ }^{2}$ Rizki Akbar Hasan, “Menilik 7 Fakta Dampak Kebakaran Hutan Amazon, Seberapa Parah?”, 31 Agustus 2019, dikutip dari https://m.liputan6.com/global/read/4051489/ menilik-7-faktadampak-kebakaran-hutan-amazon-seberapa-parah, diakses pada 1 Oktober 2019, 08:19.

${ }^{3}$ CNN Indonesia, "Membandingkan Karhutla di Indonesia Pada 2015 dan 2019”, 18 September 2019, dikutip dari https://m.cnnindonesia.com/teknologi/20190918104533-199431485/membandingkan-karhutla-di-indonesia-pada-2015-dan-2019, diakses pada 2 Oktober 2019, 9:27

${ }^{4}$ W. O. Kermack \& A. G. Mckendrick, A Contribution of The Mathematical Theory of Epidemics, Proceedings of The Royal Society of London, Series A, London: The Royal Society, 1927, hal. 700-721.
} 
merancang pencegahan, penanganan, pengobatan, dan pengendalian penyebaran suatu penyakit.

Berangkat dari QS Ar-Rum (30): 41 dan model matematika penyebaran penyakit, penelitian ini bertujuan untuk membangun model matematika yang menggambarkan penyebaran al-fasad di suatu lingkungan. Model matematika yang dibangun kemudian disimulasikan secara numerik. Dari simulasi numerik, dapat diketahui dinamika sistem yang terjadi pada model yang dibangun. Dengan kata lain, dapat diperoleh informasi tentang dinamika penyebaran alfasad dalam suatu lingkungan.

\section{B. Pengertian Al-Fasad dalam Al-Qur'an}

Bagian ini akan membahas tentang makna al-fasad secara bahasa, juga tafsir dari ayat-ayat Al-Qur'an yang menyebutkan lafadh al-fasad, dan perubahan bentuk kata dan konteks yang berkaitan dengan al-fasad.

1. Makna Etimologi

Dari sudut etimologi, kata al-fasad (الفَسَكاد) berasal dari kata kerja فَسَدَ yang berarti "rusak". Kata فَسَاد merupakan bentuk masdar, berarti kerusakan. Dari sini lahir bentuk-bentuk turunannya seperti أفْسَسْد (merusak), مُند (pelaku kerusakan), dan sebagainya.

Kerusakan adalah lawan dari kebaikan (الفساد نقيض الصلاح). Sibaweh الهُلاك الفَسَاد (kerusakan) juga memiliki kedekatan makna dengan الهَاد (kehancuran). ${ }^{5}$

2. Al-Fasad dalam Al-Quran

Di dalam Al-Qur'an, lafadh fasad disebut sebanyak enam kali, yakni pada QS Ar-Rum (30): 41, Al-Baqarah (2): 205, Ghafir (40): 26,Hud (11): 116; Al-Qashash (28): 77; Al-Fajr (89): 21.

Dalam QS Ar-Rum ayat 41, Allah Swt berfirman:

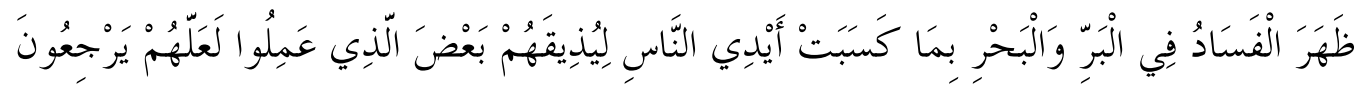

Artinya: "Telah nampak "kerusakan" di darat dan di laut disebabkan karena perbuatan tangan manusia, supaya Allah merasakan kepada mereka sebahagian dari (akibat) perbuatan mereka, agar mereka kembali (ke jalan yang benar).' (Surat Ar-Rum: 41).

Dalam Tafsir At-Tobari, arti "الفساد" dalam ayat ini dibagi menjadi dua, yakni:

\footnotetext{
${ }^{5}$ Jamaluddin bin Mandzur Al-Anshori, Lisanul Arab, Daaru Shodir, Beirut, 1414 H, Juz 3, Hal: $335-336$
} 
1. Kerusakan di darat dalam bentuk pembunuhan anak Nabi Adam As oleh saudara kandungnya sendiri.

2. Kerusakan di laut dalam bentuk perampasan/pembajakan kapal-kapal laut oleh para raja raja ${ }^{6}$ (Raja Oman Jalanda) ${ }^{7}$.

Di sinilah letak kerusakan yang dilakukan oleh tangan manusia yang mana akhirnya menyebarkan kedzaliman kepada sesama mahluk Allah Swt. Dan di ayat inilah Allah Swt menyeru para hamba-Nya untuk kembali kepada kebenaran dan bertaubat dari kedzaliman.

Ada makna lain dari kata "الفســـاد" yang disebutkan dalam tafsir Ibnu Katsir. Kata "الفســــn Menurut Ibnu Katsir bermakna kerusakan di bumi dan laut, yakni kekeringan dan kegersangan tanah dikarenakan minimnya curah hujan. Sedangkan kerusakan di laut berupa tak terlihatnya binatang-binatang di dalamnya. Dan semua kemelaratan dan kesusahan di darat dan laut tersebut adalah balasan Allah dari ketidaktaatan dan perbuatan maksiat manusia pada Allah Swt di bumi. Inilah sebab hancurnya keberkahan dari langit dan bumi.

Diriwayatkan dari Malik, dari Zaid bin Aslam, bahwa arti kata "الفساد di sini adalah kemusyrikan kepada Allah yang menyebabkan datangnya kemurkaan Allah Swt yang berujung datangnya bala' kekurangan harta, pangan dan ketentraman jiwa. ${ }^{8}$

Zamakhsyari menerangkan arti kata "الـــفســــ di sini adalah sedikitnya penghasilan dari sawah-sawah dan penjualan. Juga banyak terjadinya kematian manusia atau binatang, kebakaran dan tenggelam, kegagalan nelayan dan penyelam, dan kurangnya keberkahan dan manfaat dalam segala hal serta banyak terjadinya kemudlaratan. ${ }^{9}$

Disebutkan dalam Tafsir Ar-Rozi, bahwa sebab utama semua kerusakan yang terjadi di darat dan laut adalah kemusyrikan. Kemusyrikan yang hanya nampak dari perbuatan tanpa perkataan dan keyakinan disebut dengan kefasiqan "فســــ dan kemaksiatan "عصيان". 10

Dalam QS Al-Baqarah ayat 205, Allah SWT berfirman:

${ }^{6}$ Abu Ja'far At-Thobari, Jami'ul Bayan fi Ta'wilil Qur'an, Muassasatur Risalah, 1420 H/ 2000 M, Juz 20, Hal: 109.

${ }^{7}$ Nashiruddin Abu Sa'id Abdullah bin Umar bin Muhammad Asyairozi Al-Baidlowi, Anwaru Tanzil wa Asroru Ta'wil, Daarut Turots Al'arobi, Beirut, 1418 H, Juz 4, Hal: 208.

${ }^{8}$ Abul Fada' Isma'il bin 'Umar bin Katsir Al-qurosyi Al-Bishri, Tafsirul Qur'an Al-Adzim, Daaru Thoyyibah, 1420 H/1999 M, Juz 6, Hal: 320

${ }^{9}$ Az-Zamakhsyari, Al-Kasyaf 'An Haqoiqi Ghowamidlut Tanzil, Daarul Kitab Al-'Arabi, Beirut, 1407 H, Juz 3, Hal: 482.

${ }^{10}$ Fakhruddin Arrozi Khotiburroi, Al-Tafsir Al-Kabir, Daaru Ihyai Turots Al-'Arobi, Beirut, 1420 H, Juz 25, hal: 105. 


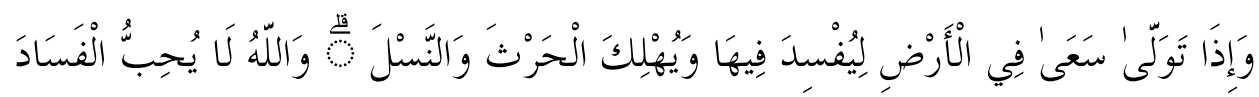

Artinya: "Dan apabila ia berpaling (dari kamu), ia berjalan di bumi untuk mengadakan kerusakan padanya, dan merusak tanam-tanaman dan binatang ternak, dan Allah tidak menyukai kebinasaan” (Surat Al-Baqarah: 205).

Ungkapan ini adalah ibarat untuk orang-orang yang berusaha menggoncangkan iman orang-orang mukmin dan selalu mengadakan pengacauan. Orang-orang tersebut (yang berpaling dari Rosulullah Saw, atau orang munafik) berusaha merusak yang ada di bumi. Mereka menghancurkan ladang, peternakan dan anak cucu keturunan mereka. Seperti yang dilakukan Akhnas bin Syuraif Al-Tsaqofi yang mengaku muslim dan mukmin di depan Rosulullah, namun ketika keluar dari rumahnya dan melewati pemukiman muslim, ia membakar pertanian dan membunuh binatang ternak mereka. Sesungguhnya Allah tidak menyukai kekacauan, penghancuran atau kedzaliman, dan Ia sangat membencinya dan tidak meridloinya serta murka dan marah kepada orang-orang yang memperlihatkan halhal hina. ${ }^{11}$

Dan tidak ada kepentingan lain bagi orang munafik selain merusak bumi, dan menghancurkan ladang atau sawah, yang merupakan sumber pertanian, perkebunan dan hewan ternak, dan dari sanalah hewan-hewan berkembang biak dan akan punah jika bumi dan peternakan dirusak.

Menurut Mujahid: arti kata "فســ adalah keadaan di mana Allah menghentikan pengairan, sehingga rusaklah atau hancurlah perkebunan dan peternakan mereka. Dan, "الفساد" di sini adalah sifat yang melekat pada diri seorang munafik. ${ }^{12}$ Orang munafik itu mencoba bermaksiat terhadap Allah di bumi-Nya. Mereka memotong jalan bagi hamba Allah dan merusaknya, seperti yang dilakukan Akhnas bin Syarif Al-Tssaqofi - sebab turunnya ayat ini karena kejadian tersebut yang mana ia membakar pertanian orang muslim dan memenggal keledai (ternak) mereka.

Dan dari Hajaj dan Ibn Jarij disebutkan bahwa maksud dari penggalan ayat

$$
\text { "سعَى في الأرض ليفسد فيها" }
$$

ialah memotong silaturahim dan menumpahkan darah (pembunuhan) terhadap orang-orang muslim. Kata "الــــــ (perusakan) di sini adalah segala jenis kemaksiatan, yaitu maksiat dengan merusak apa yang ada di bumi dan Allah Swt belum menspesifikasikan arti maksiat di sini. Dan bisa juga arti kata "الإفســـاد " adalah mereka memotong jalan atau yang lainnya. ${ }^{13}$

\footnotetext{
${ }^{11}$ Abu Sa'ud Al-'Amadi Muhammad bin Muhammad bin Mushthofa, Irsyadul Aql Ila Mazaya Al-Kitab Al-Karim, Daaru Ihyai Turots Al-'Arobi, Beirut, Juz 1, Hal: 211.

${ }^{12}$ Al-Bishri, Tafsirul Qur'an., hal. 564.

${ }^{13}$ At-Thobari, Jami'ul Bayan., hal. 239
} 
Dari penafsiran di atas dapat disimpulkan bahwa arti kata "الفساد dalam ayat ini adalah kerusakan yang bersumber dari perilaku hina orang munafik - mengaku muslim di depan Rosulullah dan melakukan hal-hal buruk selepas keluar dari rumah Rosulullah Saw - yang mencoba memusnahkan (menghancurkan) sumber kehidupan orang muslim seperti perkebunan, peternakan dan sebagainya, serta membunuh orang-orang muslim. Yang demikian adalah perlakuan hina dan keji yang sangat dibenci serta dimurkai oleh Allah Swt. Dan termasuk dalam maksiat terhadap Allah, orang lain, dan diri sendiri. Wallahu a'lam.

Dalam QS Ghafir ayat 26, Allah SWT berfirman:

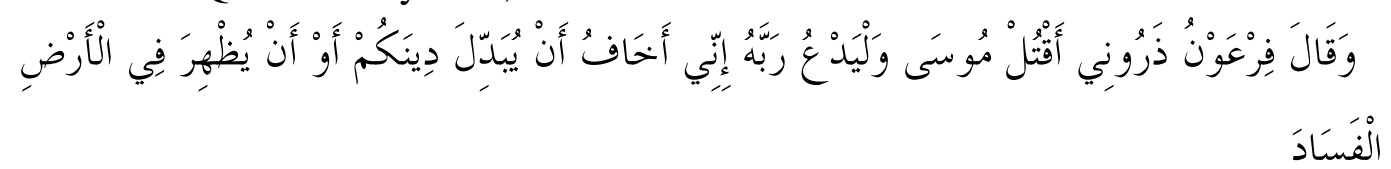

Artinya: Dan berkata Fir'aun (kepada pembesar-pembesarnya): "Biarkanlah aku membunuh Musa dan hendaklah ia memohon kepada Tuhannya, karena Sesungguhnya aku khawatir Dia akan menukar agamamu atau menimbulkan kerusakan di muka bumi" (Surat Ghafir: 26).

Makna dari إظْهَار مُوسَى الْفَسَادَ bahwa Nabi Musa As menimbulkan kerusakan bagi pengikut Raja Fir'aun adalah adanya dakwah Nabi As yang merupakan faktor atau sebab munculnya kerusakan dalam kebiasaan dan keyakinan yang mereka anut. Dan disebutkan arti الْـــــ adalah makna majaz dari peningkatan, perkembangan dan penyebaran. Dan Raja Fir'aun telah diliputi dengan keangkuhan dan kurang merenungi beberapa perkara atas kejadian yang ia anggap melanggar agama atau keyakinan yang ia anut, dan hal tersebut menyebabkan terjadinya banyak kerusakan tanpa alasan yang jelas pada agama mereka terkecuali hanya untuk mendapatkan manfaat di kehidupan dunia saja. ${ }^{14}$

Sesungguhnya adanya Nabi Musa As adalah penyebab kerusakan (bagi Fir'aun dan penganutnya) agama dan/atau dunia mereka. Kerusakan agama - Fir'aun adalah karena awalnya para penganutnya menyakini bahwa agama paling benar adalah yang bersumber dari Fir'aun yang sudah dianut bertahun-tahun, namun dengan kedatangan Nabi Musa As yang berdakwah di antara mereka, maka itu adalah perusakan bagi keyakinan kaum Fir'aun. Sedangkan kerusakan dunia adalah dengan adanya perbedaan keyakinan (pemahaman) maka itu akan menyebabkan terjadinya pertikaian dan penyebaran fitnah di antara masyarakat Fir'aun. Dan bilamana kecintaan manusia pada agama mereka lebih tinggi dari kecintaan mereka pada harta, maka tidak diragukan lagi pasti akan tersebar kerusakan di masyarakat Fir'aun. Lalu ia berkata pada para pembesar agamanya, "Sesungguhnya aku takut Hal: 126

${ }^{14}$ Ibnu 'Asyur At-Tunisi, At-Tahrir wa at-Tanwir, Addaar Attunisi, Tunis, 1984 M, Juz 24, 
Musa As akan mengganti agamamu, lalu ia akan merusak urusan (perkara) dunia, lalu ia berkata atau menyebarluaskan kerusakan di muka bumi." 15

Penyebaran kerusakan di muka bumi -bagi Fir'aun- adalah perusakan perkara dunia seperti pertikaian dan huru hara (kerusuhan) akan terjadi bilamana Nabi Musa AS berhasil menghancurkan agama mereka secara sempurna. ${ }^{16}$

Sesungguhnya aku - Fir'aun - takut Musa As akan mengganti agama kalian, yaitu ritual ibadah kalian kepadaku dengan ibadah kepada Rabbnya, atau akan muncul kerusakan di muka bumi karena apabila ia tidak merusak agamamu maka ia akan menyebarkan kerusakan di muka bumi yakni terjadinya perselisihan di antara kaum Fir'aun dikarekan keberadaan Musa As. ${ }^{17}$

Dalam QS Hud ayat 116, Allah Swt berfirman:

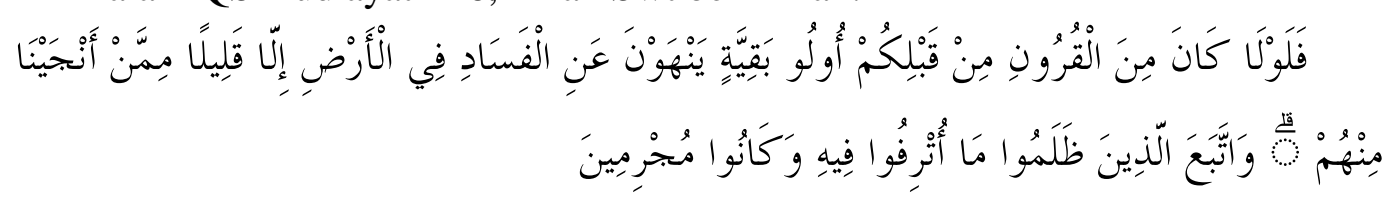

Artinya: "Maka mengapa tidak ada dari umat-umat yang sebelum kamu orang-orang yang mempunyai keutamaan yang melarang dari (mengerjakan) kerusakan di muka bumi, kecuali sebahagian kecil di antara orang-orang yang telah Kami selamatkan di antara mereka, dan orang-orang yang zalim hanya mementingkan kenikmatan yang mewah yang ada pada mereka, dan mereka adalah orang-orang yang berdosa." (Surat Hud: 116).

Kata "الفساد" di ayat ini diartikan sebagai maksiat dalam berbagai macam keadaan atau bentuknya, yang mana di sini diartikan sebagai larangan bagi manusia akhir zaman untuk melakukan maksiat atau terjerumus di dalamnya atau berlaku sembrono di dunia ini. Dengan ini Allah Swt menginginkan seluruh umat Islam dalam keadaan baik, tidak masuk ke dalam suatu kehinaan atau kehancuran sebagaimana terjadi pada Bani Israil yang telah musnah dihancurkan oleh Allah Swt. Ayat ini membahas tentang keistimewaan shohabah Nabi Saw. Mereka adalah sebagian dari kaum Quraisy yang menyeru kepada iman sampai seluruhnya beriman. Dan sebagian kecil lainnya menyeru pada iman dan istiqomah setelah masuk Islam dan mengajari tentang agama ${ }^{18}$, sebagaimana firman Allah Swt pada QS Ali Imron (3): 110 berikut:

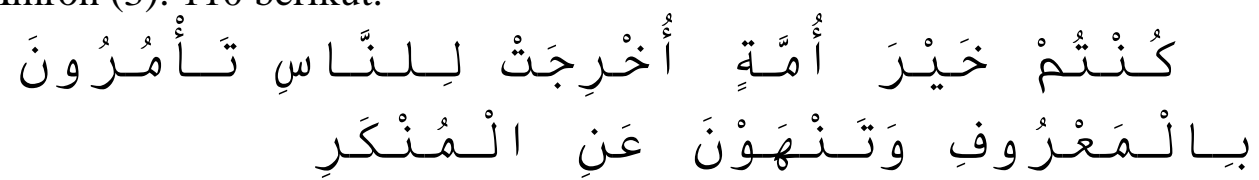

Artinya: "Kamu adalah umat yang terbaik yang dilahirkan untuk manusia, menyuruh kepada yang ma'ruf, dan mencegah dari yang munkar, ...”.

\footnotetext{
${ }^{15}$ Khotiburroi, Al-Tafsir., hal 507.

${ }^{16}$ Baidlowi, Anwaru Tanzil., hal. 55.

${ }^{17}$ Al-Qurthubi, Al-Jami' Li Ahkami al-Qur'an, Daarul Kutub Al Mishriah, Kairo, 1384 H/1963 M, Juz 15, Hal: 305.

${ }^{18}$ At-Tunisi, At-Tahrir., hal. 184.
} 
Kata "الفســ di sini diartikan sebagai maksiat seperti yang dijelaskan sebelumnya. Mereka melarang ahli maksiat untuk tidak lagi bermaksiat, dan orang kafir kepada Allah tidak lagi kafir kepadaNya, atau seruan untuk segera beriman di muka bumi. ${ }^{19}$ Dari sini bisa disimpulkan bahwa maksiat bukan hanya dapat terjadi antara manusia saja, namun kafir terhadap Allah pun masuk dalam kategori maksiat, yakni kepada Allah Swt dan diri sendiri. Wallahu a'lam.

Dalam QS Al-Qashash ayat 77, Allah Swt berfirman:

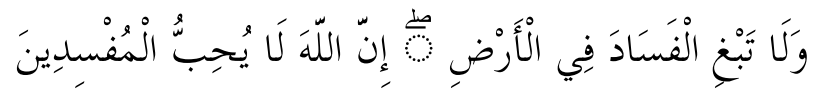

Artinya:“... dan janganlah kamu berbuat kerusakan di (muka) bumi. Sesungguhnya Allah tidak menyukai orang-orang yang berbuat kerusakan." (Surat Al-Qashash: 77).

Kalimat 'dan janganlah kamu berbuat kerusakan di bumi' berisi peringatan untuk menjauhi tidakan yang mencampur-adukan antara kebaikan dengan keburukan karena keburukan berlawanan dengan kebaikan, dan juga merupakan kalimat perintah untuk menyebarkan (melakukan) kebaikan, dan larangan untuk keburukan. Dan disebutkan juga bahwa jika ada satu keburukan yang membersamai beberapa kebaikan maka perkara tersebut dikategorikan sebagai keburukan.

Dan kalimat "sesungguhnya Allah tidak menykai orang-orang yang berbuat kerusakan" adalah alasan adanya larangan terhadap keburukan, karena amalan yang tidak disukai Allah, maka hambanNya tidak diperbolehkan untuk melakukannya. ${ }^{20}$ Dalam konteks ini Allah melarang menyebarkan kedzoliman dan kedengkian (keaniayaan), sesungguhnya Allah Swt tidak menyukai para perusak dengan perangai (pekerjaan)-nya yang buruk. ${ }^{21}$

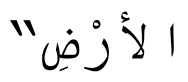
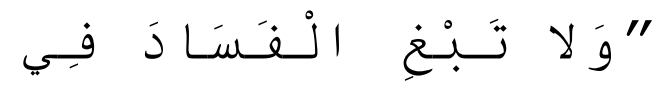

yakni jangan jadikan kepentinganmu dalam hidup untuk merusak apa yang ada di muka bumi, dan berlaku buruk kepada Allah Swt, sesungguhnya Allah tidak menyukai orang orang yang merusak. ${ }^{22}$

Dalam QS Al-Fajr ayat 21, Allah SWT berfirman:

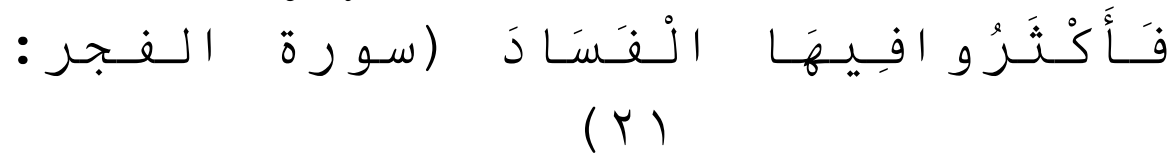

Artinya: "Lalu mereka berbuat banyak kerusakan dalam negeri itu."

Kerusakan adalah keadaan buruk dalam suatu hal atau perkara dan terdapat bahaya di dalamnya. Dalam al-Quran Allah Swt berfirman: "Dan apabila ia berpaling (dari kamu), ia berjalan di bumi untuk mengadakan kerusakan padanya, dan merusak tanam-tanaman dan binatang ternak." (Al-Baqoroh: 205).

\footnotetext{
${ }^{19}$ At-Thobari, Jami'ul Bayan., hal. 527.

${ }^{20}$ At-Tunisi, At-Tahrir., hal. 180

${ }^{21}$ Al-Baidlowi, Anwaru Tanzil., hal. 185.

${ }^{22}$ Al-Bishri, Tafsirul Qur'an., hal. 254
} 
Dan lawan dari keburukan adalah kebaikan. Allah Swt berfirman: "Dan janganlah kamu berbuat kerusakan di bumi setelah (diciptakan) dengan baik” (AlA'raf: 56). Dan banyak dari perbuatan keburukan adalah sebab dari kemarahan Allah Swt, dan Allah tidak menyukai perbuatan buruk, karenanya Allah akan menimpakan kepada mereka adzab. ${ }^{23}$ Mereka sering melakukan perbuatan yang merusak di muka bumi dengan kekufuran dan kedzoliman. ${ }^{24}$ Allah Swt menyebutkan bahwa mereka memperbanyak keburukan di bumi dengan maksiat dan mengambil (melakukan) apa yang diharamkan oleh Allah Swt atas mereka. ${ }^{25}$ Al-Fasad adalah ketidakadilan, kekejaman, penindasan dan penganiayaan. ${ }^{26}$

Maka mereka banyak melakukan keburukan di bumi yang mana ia adalah lawan dari kebaikan, yang mana sesungguhnya di dalam kebaikan akan mendapatkan (menimbulkan) berbagai macam al-birr, dan dari keburukan akan menghasilkan berbagai macam itsm, dan barang siapa mengerjakan amalan di luar perintah Allah Swt dan memperlakukan hamba-Nya dengan kedzoliman maka ia merupakan seorang perusak. ${ }^{27}$

\section{Metode Penelitian}

Langkah-langkah yang dilakukan dalam penelitian ini mempunyai alur sebagaimana disajikan oleh Gambar 1. Langkah pertama penelitian ini adalah kajian lafadh al-fasad, baik secara bahasa maupun berdasarkan tafsir ayat AlQur'an. Dari kajian lafadh yang dilakukan, diperoleh konsep al-fasad yang meliputi pelaku, penyebab dan pencegahannya. Setelah itu, dilakukan simplifikasi masalah sebagai dasar konstruksi model matematika. Model matematika disimulasikan secara numerik menggunakan Metode Runge-Kutta Orde Empat. ${ }^{28}$ Terakhir, hasil dari simulasi numerik diinterpretasikan dan ditarik simpulan.

\footnotetext{
${ }^{23}$ At-Tunisi, At-Tahrir., hal. 322.

24 Al-Baidlowi, Anwaru Tanzil., hal. 310.

${ }^{25}$ At-Thobari, Jami'ul Bayan., hal. 410.

${ }^{26}$ Al-Qurthubi, Al-Jami' Li Ahkami., hal. 49.

${ }^{27}$ Khotiburroi, Al-Tafsir., hal. 154.

${ }^{28}$ D. K. Chaturvedi, Modeling and Simulation of Systems Using MATLAB and Simulink, CRC
} Press, Florida, USA, 2010 


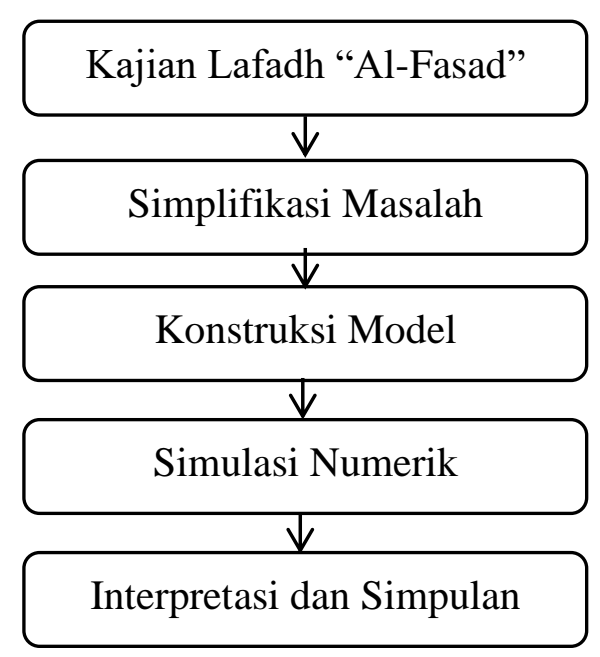

Gambar 1. Diagram Alir Metode Penelitian

\section{Hasil Dan Pembahasan}

\section{Konstruksi Model Matematika}

Pada bagian ini, dibangun model matematika penyebaran penyakit, dengan asumsi bahwa al-fasad adalah suatu penyakit menular. Berdasarkan kajian lafadh yang telah dilakukan, al-fasad diidap oleh kaum Musyrik, Kafir, Munafiq, dan Fasiq. Untuk penyederhanaan masalah, dalam penelitian ini, dianggap tidak ada kaum Musyrik dan Kafir dalam lingkup lingkungan yang diamati. Sedangkan Munafiq dan Fasiq diasumsikan menjadi satu subpopulasi, yakni Faasid. Dengan kata lain, dalam hal ini konstruksi model matematika penyebaran al-fasad, mempertimbangkan bahwa pada suatu lingkungan, memiliki total populasi $(N)$ yang terdiri dari empat subpopulasi, yakni Muslim $\left(M_{1}\right)$, Mukmin $\left(M_{2}\right)$, Muhsin $\left(M_{3}\right)$, dan Faasid $(F)$.

Muslim $\left(M_{1}\right)$ adalah semua individu yang beragama Islam, tapi belum tentu melakukan syariat Islam dengan baik dan benar. Mukmin $\left(M_{2}\right)$ adalah semua individu yang beragama Islam, dan melakukan syariat Islam dengan baik dan benar. Muhsin $\left(M_{3}\right)$ adalah semua individu yang beragama Islam, melakukan syariat dengan baik dan benar, serta beribadah seolah melihat Allah Swt. Sedangkan Munafiq dan Fasiq adalah semua individu yang beragama Islam, namun melakukan kerusakan, baik secara lahir maupun batin, kepada diri sendiri maupun orang lain, terhadap alam maupun sosial. Dalam hal ini dapat dikatakan bahwa Munafiq dan Fasiq adalah individu yang terinfeksi al-fasad, atau disebut Faasid $(F)$.

Batasan masalah dan asumsi yang diterapkan dalam proses konstruksi model matematika penyebaran al-fasad adalah sebagai berikut:

1. Lingkungan bersifat homogen, semua penduduknya beragama Islam. 
2. Lingkungan bersifat tertutup, artinya tidak ada individu yang keluar ataupun masuk lokasi.

3. Terdapat kelahiran dan kematian alami dalam semua subpopulasi.Semua kelahiran, baik dari subpopulasi $M_{1}, M_{2}, M_{3}$, maupun $F$, diasumsikan sebagai individu muslim, sehingga menambah jumlah subpopulasi $M_{1}$.

4. Pengaruh faktor internal terhadap keimanan individu, seperti turunnya keimanan dikarenakan maksiat yang dilakukan, atau naiknya keimanan karena pengaruh kebaikan, ibadah, atau pertaubatan individu, dianggap tidak ada.

5. Peningkatan dan penurunan keimanan, hanya dipengaruhi oleh interaksi dengan individu dari subpopulasi lain.

6. Tingkatan keimanan dan ketaqwaan dimulai dari $M_{1}$, kemudian $M_{2}$, lalu $M_{3}$. Masing-masing subpopulasi mempunyai kekuatan dakwah tertentu, di mana kekuatan dakwah $M_{3}$ lebih besar daripada $M_{2}$, dan kekuatan dakwah $M_{2}$ lebih besar daripada $M_{1}$. Akibatnya, adanya interaksi antara $M_{1}$ dengan $M_{2}$ akan mengurangi jumlah subpopulasi $M_{1}$ dan menambah jumlah subpopulasi $M_{2}$. Adanya interaksi $M_{2}$ dengan $M_{3}$ akan mengurangi subpopulasi $M_{2}$ dan menambah jumlah subpopulasi $M_{3}$.

7. Penyakit al-fasad ditularkan melalui interaksi dengan individu terinfeksi, yakni $F$. Subpopulasi $M_{1}, M_{2}$, dan $M_{3}$ dapat tertular al-fasad dengan laju penularan tertentu.

8. Individu dalam subpopulasi $M_{1}, M_{2}$, dan $M_{3}$, masing-masing mempunyai tingkat kerentanan terhadap al-fasad, misal $\mu_{1}, \mu_{2}, \mu_{3}$.

9. Terdapat dua kemungkinan yang diakibatkan oleh adanya interaksi subpopulasi $M_{3}$ dengan $F$. Kemungkinan pertama, interaksi tersebut mengakibatkan penurunan iman $M_{3}$, sehingga menjadi $M_{2}$. Kemungkinan kedua, interaksi tersebut mengakibatkan peningkatan iman $F$, sehingga menjadi $M_{1}$. Hal ini terjadi dengan laju interaksi tertentu, misalkan $\theta_{3}$.

10. Hal yang sama juga berlaku pada interaksi $M_{2}$ dengan $F$. Interaksi tersebut dapat membuat $M_{2}$ mengalami penurunan iman dan tergolong subpopulasi $M_{1}$, atau mengakibatkan $F$ mengalami peningkatan iman sehingga menjadi $M_{1}$. Hal ini terjadi dengan laju interaksi tertentu, misalkan $\theta_{2}$.

11. Begitu pula interaksi antara subpopulasi $M_{1}$ dengan $F$. Interaksi tersebut dapat mengakibatkan $M_{1}$ menjadi $F$, atau $F$ menjadi $M_{1}$. Hal ini terjadi dengan laju interaksi tertentu, misalkan $\theta_{1}$.

12. Laju atau tingkat interaksi antara subpopulasi faasid dengan subpopulasi yang lain, yakni $\theta_{1}, \theta_{2}$, dan $\theta_{3}$, memiliki nilai yang tidak sama. Dalam hal ini, $\theta_{1}>$ $\theta_{2}>\theta_{3}$. Artinya tingkat interaksi subpopulasi muslim dengan faasid lebih tinggi daripada tingkat interaksi subpopulasi mukmin dengan faasid, dan tingkat interaksi subpopulasi mukmin dengan faasid lebih tinggi daripada tingkat interaksi subpopulasi muhsin dengan faasid. 
13. Terdapat stiffness coefficient dalam proses peningkatan maupun penurunan keimanan.

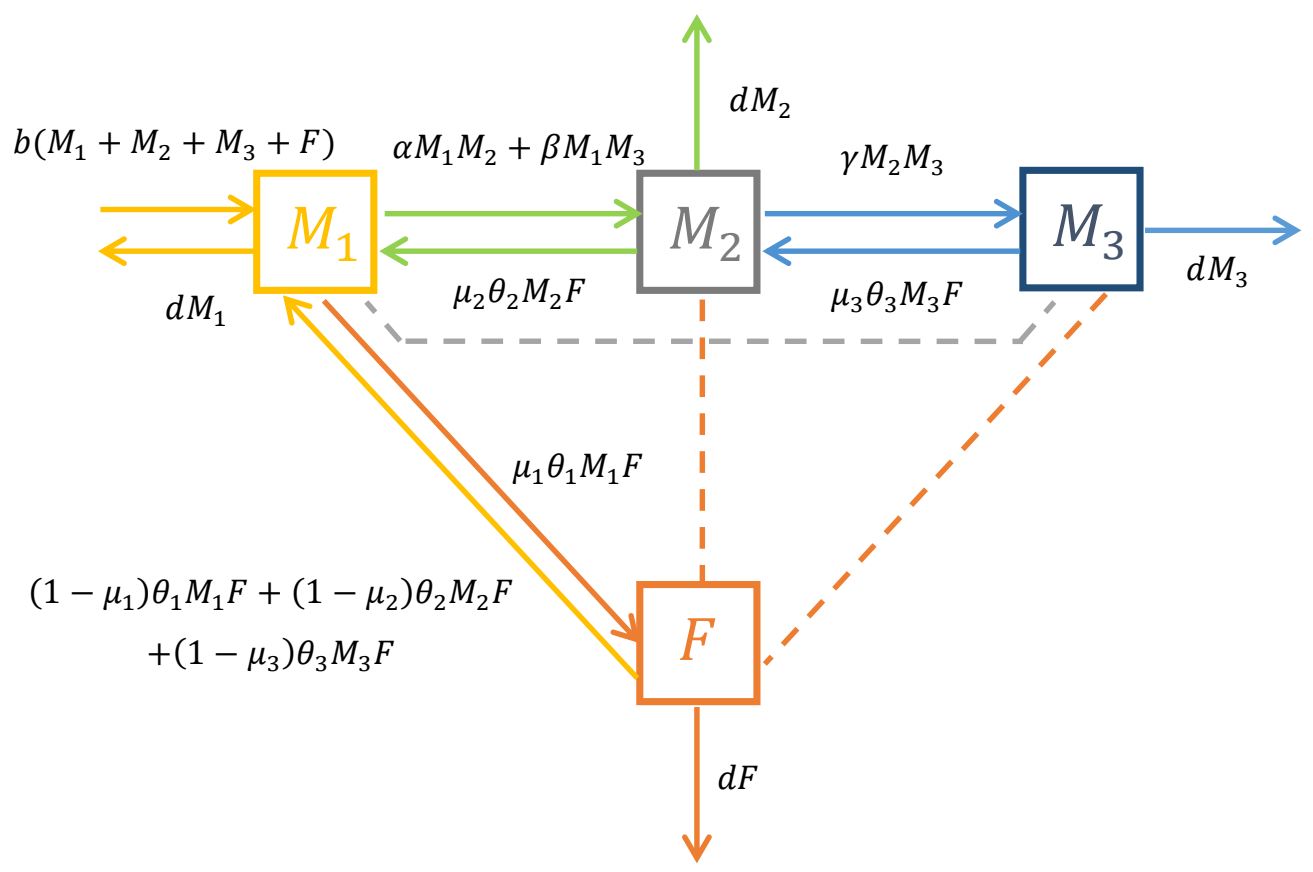

Gambar 2. Diagram Kompartemen Penularan Al-Fasad

Berdasarkan batasan dan asumsi yang diterapkan, diperoleh diagram kompartemen dari model matematika penyebaran al-fasad dalam lingkungan muslim, yang disajikan oleh Gambar 2. Garis putus-putus dalam diagram alir merepresentasikan adanya interaksi antara dua subpopulasi, namun tidak secara langsung memberikan penambahan atau pengurangan terhadap jumlah subpopulasi.

Secara matematis, dinamika penyebaran al-fasad dalam suatu lingkungan muslim yang telah dikonstruksi dapat dinyatakan oleh sistem persamaan diferensial biasa (1)-(5).

$$
\begin{aligned}
\frac{d M_{1}}{d t}= & b\left(M_{1}+M_{2}+M_{3}+F\right)-d M_{1}-\alpha M_{1} M_{2}-\beta M_{1} M_{3}-\mu_{1} \theta_{1} M_{1} F \\
& +\phi_{1}\left[\left(1-\mu_{1}\right) \theta_{1} M_{1}+\left(1-\mu_{2}\right) \theta_{2} M_{2}+\left(1-\mu_{3}\right) \theta_{3} M_{3}\right] F \\
& +\phi_{2} \mu_{2} \theta_{2} M_{2} F \\
\frac{d M_{2}}{d t}= & -d M_{2}+\phi_{1} \alpha M_{1} M_{2}+\phi_{1} \beta M_{1} M_{3}-\gamma M_{2} M_{3}-\mu_{2} \theta_{2} M_{2} F \\
& +\phi_{2} \theta_{3} \mu_{3} M_{3} F \\
\frac{d M_{3}}{d t}= & -d M_{3}+\phi_{1} \gamma M_{2} M_{3}-\mu_{3} \theta_{3} M_{3} F \\
\frac{d F}{d t}= & -d F-\left(\left(1-\mu_{1}\right) \theta_{1} M_{1}+\left(1-\mu_{2}\right) \theta_{2} M_{2}+\left(1-\mu_{3}\right) \theta_{3} M_{3}\right) F \\
& +\phi_{2} \mu_{1} \theta_{1} M_{1} F \\
N= & M_{1}+M_{2}+M_{3}+F
\end{aligned}
$$


Dengan parameter-parameter dalam sistem adalah

$b$ : laju kelahiran,

$d$ : laju kematian alami,

$\alpha$ : laju interaksi antara subpopulasi muslim dan mukmin,

$\beta$ : laju interaksi antara subpopulasi muslim dan muhsin,

$\gamma$ : laju interaksi antara subpopulasi mukmin dan muhsin,

$\theta_{1}$ : laju interaksi antara subpopulasi muslim dengan faasid,

$\theta_{2}$ : laju interaksi antara subpopulasi mukmin dengan faasid,

$\theta_{3}$ : laju interaksi antara subpopulasi muhsin dengan faasid,

$\mu_{1}$ : proporsi subpopulasi muslim yang rentan terhadap alfasad,

$\mu_{2}$ : proporsi subpopulasi mukmin yang rentan terhadap alfasad,

$\mu_{3}$ : proporsi subpopulasi muhsin yang rentan terhadap alfasad,

$\left(1-\mu_{1}\right)$ : proporsi subpopulasi muslim yang kebal terhadap alfasad,

$\left(1-\mu_{2}\right)$ : proporsi subpopulasi mukmin yang kebal terhadap alfasad,

$\left(1-\mu_{3}\right)$ : proporsi subpopulasi muhsin yang kebal terhadap alfasad,

$\phi_{1}$ : koefisien proses peningkatan iman,

$\phi_{2}$ : koefisienproses penurunan iman.

Misalkan variabel non dimensional $m_{1}=\frac{M_{1}}{N}, m_{2}=\frac{M_{2}}{N}, m_{3}=\frac{M_{3}}{N}, f=\frac{F}{N}$, di mana $m_{1}, m_{2}, m_{3}$, dan $f$ adalah proporsi jumlah subpopulasi terhadap total populasi, maka sistem (1)-(5) dapat ditulis sebagai sistem (6)-(10).

$$
\begin{aligned}
\frac{d m_{1}}{d t}= & b-d m_{1}-\alpha m_{1} m_{2}-\beta m_{1} m_{3}-\mu_{1} \theta_{1} m_{1} f+\phi_{2} \mu_{2} \theta_{2} m_{2} f \\
& +\phi_{1}\left[\left(1-\mu_{1}\right) \theta_{1} m_{1}+\left(1-\mu_{2}\right) \theta_{2} m_{2}+\left(1-\mu_{3}\right) \theta_{3} m_{3}\right] f \\
\frac{d m_{2}}{d t}= & -d m_{2}+\phi_{1} \alpha m_{1} m_{2}+\phi_{1} \beta m_{1} m_{3}-\gamma m_{2} m_{3}-\mu_{2} \theta_{2} m_{2} f \\
& +\phi_{2} \theta_{3} \mu_{3} m_{3} f \\
\frac{d m_{3}}{d t}= & -d m_{3}+\phi_{1} \gamma m_{2} m_{3}-\mu_{3} \theta_{3} m_{3} f \\
\frac{d f}{d t}= & -d f-\left(\left(1-\mu_{1}\right) \theta_{1} m_{1}+\left(1-\mu_{2}\right) \theta_{2} m_{2}+\left(1-\mu_{3}\right) \theta_{3} m_{3}\right) f \\
& +\phi_{2} \mu_{1} \theta_{1} m_{1} f \\
m_{1}+ & m_{2}+m_{3}+f=1
\end{aligned}
$$

Pada bagian selanjutnya, dilakukan simulasi numerik dari sistem persamaan (6)(10).

\section{Simulasi Numerik}

Simulasi numerik dilakukan dengan menggunakan metode Runge-Kutta Orde Empat. Nilai-nilai parameter yang digunakan dalam simulasi disebutkan dalam 
Tabel 1. Tingkat kelahiran dan kematian diolah dari data BPS tahun 2015, ${ }^{29}$ sedangkan nilai parameter lainnya digunakan asumsi probabilitas atau prosentase. Jumlah penduduk Indonesia pada tahun 2015 diperkirakan sebanyak 250,67 juta, jumlah kelahiran diperkirakan 4,88 juta, dan jumlah kematian sebanyak 1,61 juta. Dengan menghitung rasio jumlah kelahiran dengan jumlah penduduk, diperoleh tingkat kelahiran. Dan dengan menghitung rasio jumlah kematian dengan jumlah penduduk, diperoleh tingkat kematian.

Tabel 1. Nilai Parameter dalam Simulasi Numerik Skenario A

\begin{tabular}{|c|l|}
\hline Parameter & \multicolumn{1}{|c|}{ Nilai } \\
\hline$b$ & 0.0195 \\
\hline$d$ & 0.0064 \\
\hline$\alpha$ & 0,5 \\
\hline$\beta$ & 0,5 \\
\hline$\gamma$ & 0,5 \\
\hline$\theta_{1}$ & 0,4 \\
\hline$\theta_{2}$ & 0,3 \\
\hline$\theta_{3}$ & 0,2 \\
\hline$\phi_{1}$ & 1 \\
\hline$\phi_{2}$ & 1 \\
\hline
\end{tabular}

Dalam simulasi numerik penelitian ini, dilakukan tiga macam skenario. Ketiga skenario memiliki asumsi tingkat kerentanan yang berbeda-beda terhadap al-fasad. Pada Skenario A, diasumsikan bahwa $\mu_{1}>\mu_{2}>\mu_{3}$. Artinya $M_{1}$ lebih rentan terinfeksi alfasad daripada $M_{2}$, dan $M_{2}$ lebih rentan terinfeksi daripada $M_{3}$. Dalam hal ini digunakan nilai $\mu_{1}=0,4, \mu_{2}=0,3$, dan $\mu_{3}=0,2$. Skenario $\mathrm{B}$ mengasumsikan nilai $\mu_{1}=\mu_{2}=\mu_{3}=1$. Sedangkan skenario $\mathrm{C}$, digunakan nilai $\mu_{1}=\mu_{2}=\mu_{3}=0$.

Dalam masing-masing skenario, diberlakukan empat macam keadaan. Keadaan pertama, tidak terdapat individu yang terjangkit al-fasad, atau $f=0$. Keadaan kedua, ketiga dan keempat, $f \neq 0$. Keadaan kedua, kondisi awal sistem memiliki prosentase subpopulasi yang terinfeksi alfasad $(f)$ kurang dari $25 \%$. Keadaan ketiga, kondisi awal sistem memiliki prosentase subpopulasi $f$ sama dengan 50\%. Keadaan keempat, kondisi awal sistem memiliki prosentase subpopulasi $f$ lebih dari $75 \%$. Keempat kondisi awal yang diterapkan pada masingmasing skenario, ditunjukkan oleh Tabel 2.

Tabel 2. Kondisi Awal dalam Simulasi Numerik

${ }^{29}$ Subdirektorat Statistik Demografi Badan Pusat Statistik, Proyeksi Penduduk Indonesia 2010-2035, Badan Pusat Statistik, Jakarta, 2013. 


\begin{tabular}{|c|c|c|c|c|}
\hline $\begin{array}{c}\text { Kondisi } \\
\text { awal }\end{array}$ & $\begin{array}{c}\text { Subpopulasi } \\
\text { Muslim }\end{array}$ & $\begin{array}{c}\text { Subpopulasi } \\
\text { Mukmin }\end{array}$ & $\begin{array}{c}\text { Subpopulasi } \\
\text { Muhsin }\end{array}$ & $\begin{array}{c}\text { Subpopulasi } \\
\text { Faasid }\end{array}$ \\
\hline 1 & $m_{1_{0}}=25$ & $m_{2_{0}}=25$ & $m_{3_{0}}=50$ & $f_{0}=0$ \\
\hline 2 & $m_{1_{0}}=20$ & $m_{2_{0}}=20$ & $m_{3_{0}}=40$ & $f_{0}=20$ \\
\hline 3 & $m_{1_{0}}=10$ & $m_{2_{0}}=20$ & $m_{3_{0}}=20$ & $f_{0}=50$ \\
\hline 4 & $m_{1_{0}}=5$ & $m_{2_{0}}=5$ & $m_{3_{0}}=10$ & $f_{0}=80$ \\
\hline
\end{tabular}

Kondisi awal dalam Tabel 2 merepresentasikan keadaan mula-mula dari suatu lingkungan yang diamati. Kondisiawal pertama berarti bahwa mula-mula suatu lingkungan terdiri dari 25\% Muslim, 25\% Mukmin, 50\% Muhsin dan 0\% terinfeksi al-fasad, atau tidak terdapat individu yang terjangkit al-fasad. Kondisi awal kedua, mula-mula suatu lingkungan terdiri dari 20\% Muslim, 20\% Mukmin, 40\% Muhsin dan $20 \%$ terinfeksi al-fasad. Pada kondisi awal ketiga, mula-mula lingkungan terdiri dari 10\% Muslim, 20\% Mukmin, 20\% Muhsin, dan 50\% Faasid. Sedangkan keempat, keadaan mula-mula suatu lingkungan adalah mayoritas Faasid, yakni sebesar 80\%. Subpopulasi Muslim hanya 5\%, Mukmin 5\%, dan Muhsin 10\%.

Gambar 3 adalah hasil dari simulasi numerik untuk Skenario A. Melalui Gambar 3, dapat diamati dinamika yang terjadi dalam lingkungan yang memiliki tingkat kerentanan $\mu_{1}=0,4, \mu_{2}=0,3$, dan $\mu_{3}=0,2$ terhadap al-fasad. Berdasarkan Gambar 3, diketahui bahwa untuk skenario semacam ini, berapapun rasio Muslim, Mukmin, Muhsin, dan Faasid dalam suatu lingkungan, pada akhirnya, semua penduduk masuk dalam golongan Muhsin. Hal ini diakibatkan oleh masih terdapat kekebalan yang dimiliki oleh Muslim, Mukmin, dan Muhsin terhadap al-fasad. Dengan tingkat kerentanan $\mu_{1}=0,4, \mu_{2}=0,3$, dan $\mu_{3}=0,2$, diketahui bahwa terdapat kekebalan sebesar 0,6 oleh Muslim, 0,7 oleh Mukmin, dan 0,8 oleh Muhsin.

Melalui perbandingan Gambar 3a, 3b, 3c, dan 3d, diketahui bahwa yang menjadi perbedaan dalam Skenario A adalah waktu yang diperlukan untuk mencapai keadaan lingkungan 100\% Muhsin. Pada Gambar 3a, di mana sejak awal tidak ada individu yang terjangkit al-fasad, memiliki waktu tempuh lebih cepat dari yang lain dalam mencapai keadaan 100\% Muhsin. Sedangkan pada Gambar 3d, yang keadaan awal lingkungannya adalah mayoritas Faasid, memerlukan waktu lebih lama dari yang lain untuk mencapai keadaan 100\% Muhsin. 


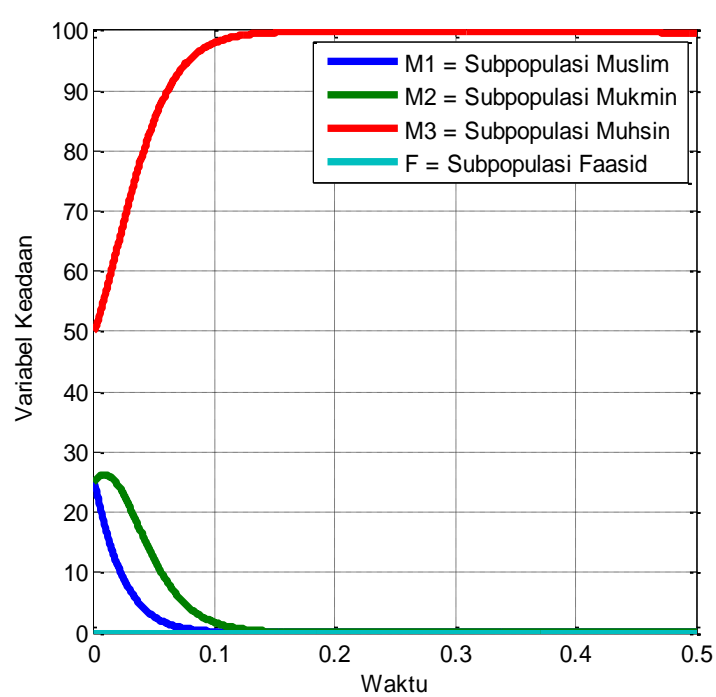

(a) Kondisi Awal $M_{1}: M_{2}: M_{3}: F=$ 25: $25: 50: 0$

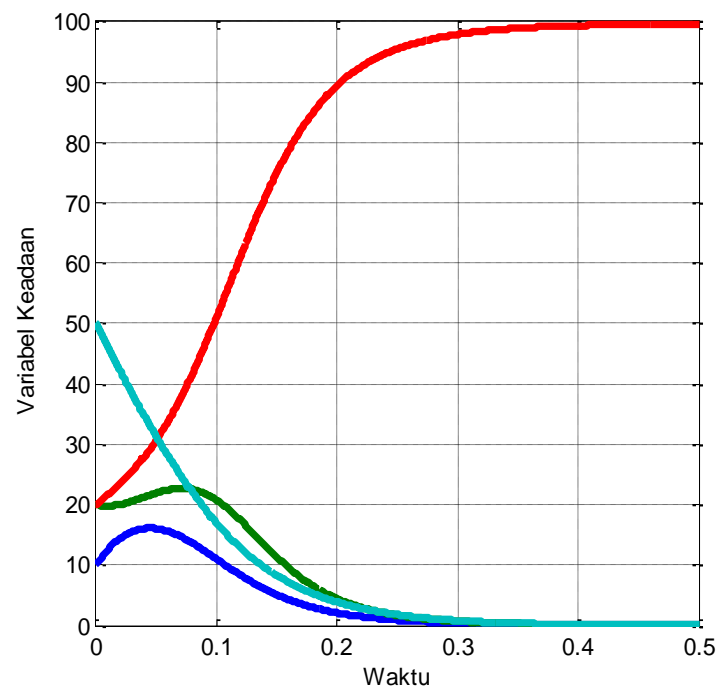

(c) Kondisi Awal $M_{1}: M_{2}: M_{3}: F=$ 10: 20: 20: 50

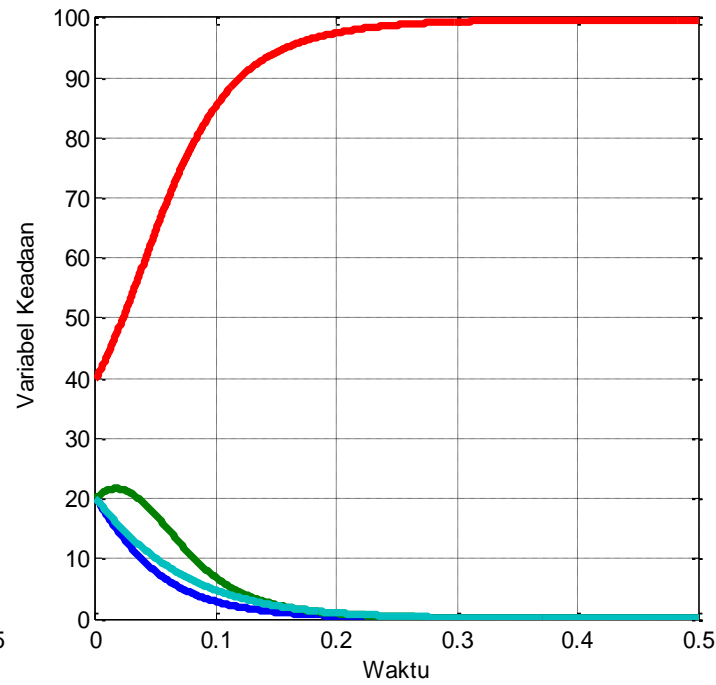

(b) Kondisi Awal $M_{1}: M_{2}: M_{3}: F=$ 20: $20: 40: 20$

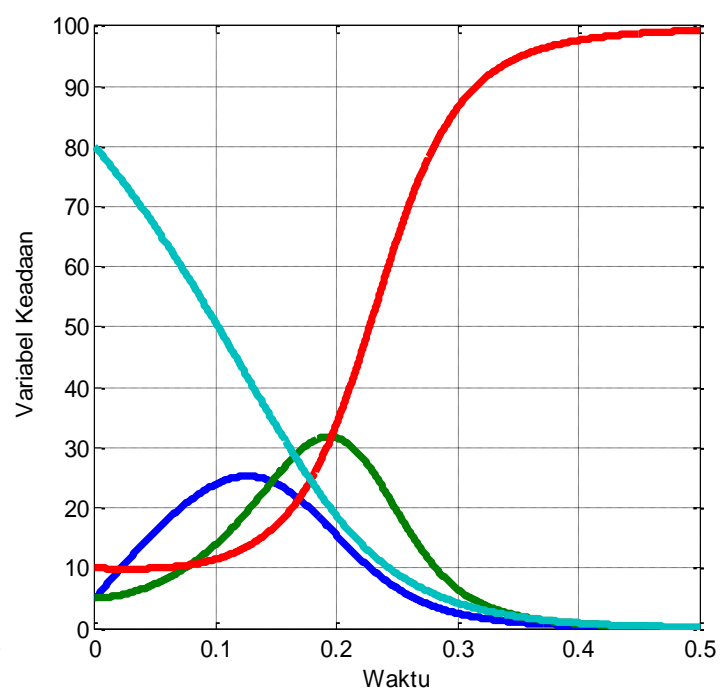

(d) Kondisi Awal $M_{1}: M_{2}: M_{3}: F=$ 5: 5: $10: 80$

Gambar 3. Dinamika Populasi Muslim-Mukmin-Muhsin-Faasid dalam Suatu Lingkungandengan Tingkat Kerentanan $\boldsymbol{\mu}_{\mathbf{1}}>\boldsymbol{\mu}_{\mathbf{2}}>\boldsymbol{\mu}_{\mathbf{3}}$ terhadap Al-Fasad

Dalam Skenario B, diterapkan nilai parameter $\mu_{1}=\mu_{2}=\mu_{3}=1$. Artinya, tingkat kerentanan seorang individu adalah $100 \%$ terhadap penyakit al-fasad, dengan kata lain jika terjadi interaksi dengan Faasid, individu tersebut pasti tertular al-fasad. Hasil simulasi numerik untuk Skenario B ditunjukkan oleh Gambar 4. 


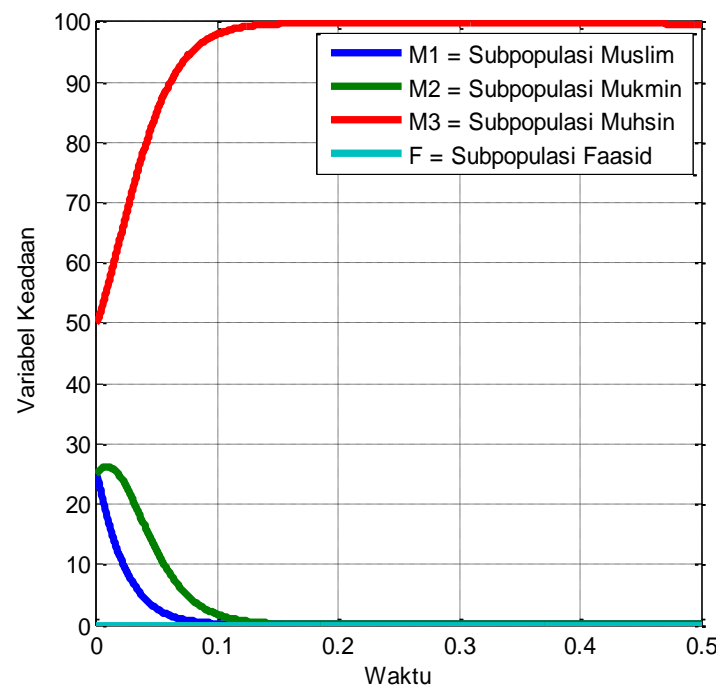

(a) Kondisi Awal $M_{1}: M_{2}: M_{3}: F=$ 25: 25: 50: 0

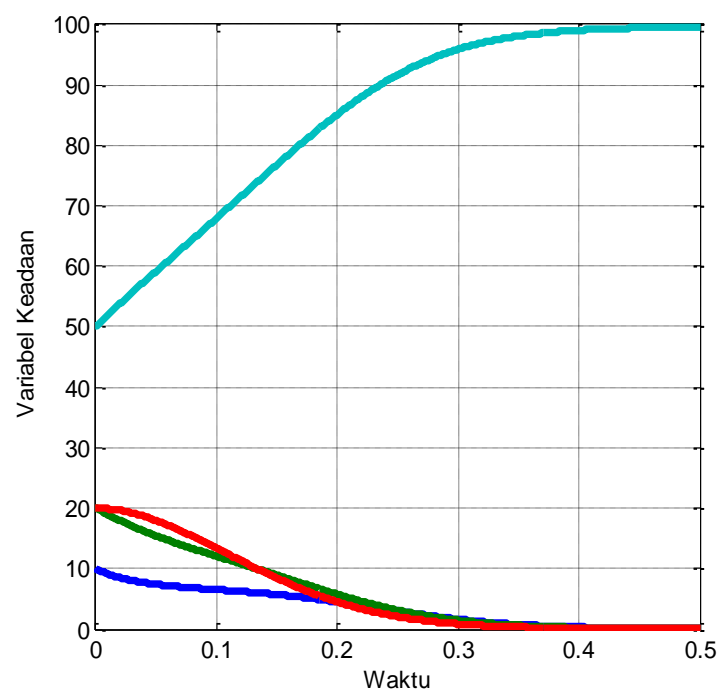

(c) Kondisi Awal $M_{1}: M_{2}: M_{3}: F=$ 10: 20: 20: 50

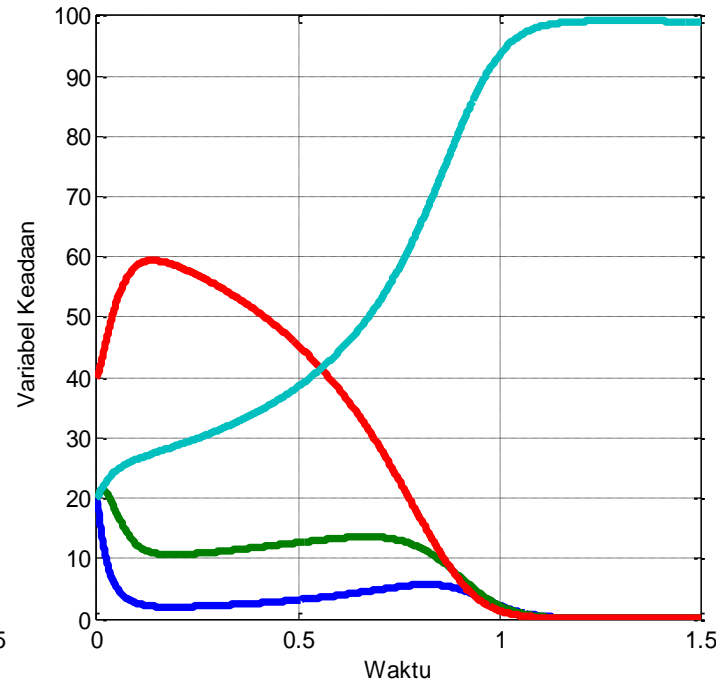

(b) Kondisi Awal $M_{1}: M_{2}: M_{3}: F=$ 20: $20: 40: 20$

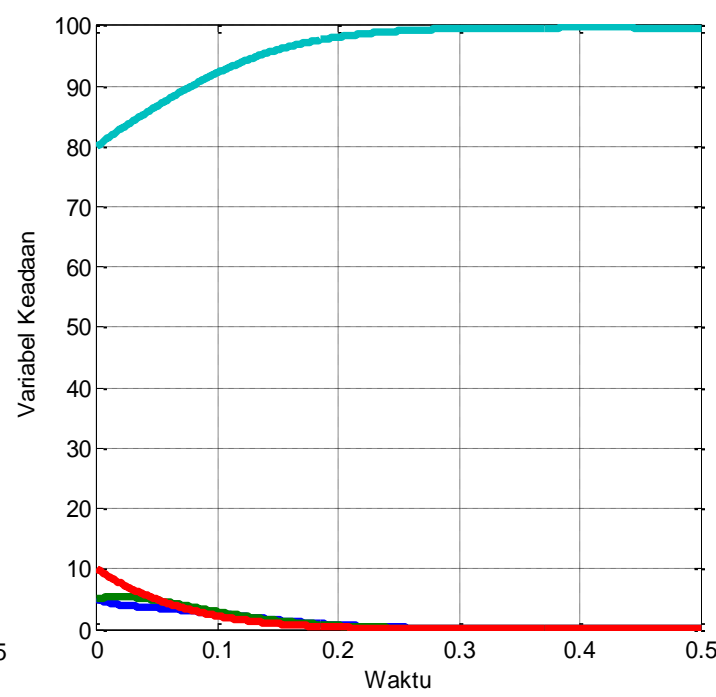

(d) Kondisi Awal $M_{1}: M_{2}: M_{3}: F=$ 5: 5: $10: 80$

Gambar 4. Dinamika Populasi Muslim-Mukmin-Muhsin-Faasid dalam Suatu Lingkungan dengan Tingkat Kerentanan 100\% Terhadap Al-Fasad

Berdasarkan Gambar 4a, jelas bahwa tingkat kerentanan 100\% terhadap alfasad tidak berpengaruh pada lingkungan yang tidak terdapat Faasid di dalamnya. Sedangkan dari Gambar 4b, 4c, dan 4d, diketahui bahwa dengan tingkat kerentanan $100 \%$, semua individu dalam subpopulasi Muslim, Mukmin, dan Muhsin dalam suatu lingkungan pada suatu waktu tertentu tertular penyakit alfasad, dan semua masyarakatnya tergolong Faasid. Melalui perbandingan Gambar 4b, 4c, dan 4d, diketahui bahwa dalam skenario B, semakin banyak jumlah individu yang tergolong Faasid dalam kondisi mula-mula, maka semakin cepat suatu lingkungan menjadi $100 \%$ Faasid. Begitu pula sebaliknya. 
Dalam skenario $\mathrm{C}$, digunakan nilai $\mu_{1}=\mu_{2}=\mu_{3}=0$. Artinya, subpopulasi Muslim, Mukmin, dan Muhsin mempunyai tingkat kerentanan 0\% terhadap alfasad. Dengan kata lain, subpopulasi Muslim, Mukmin, dan Muhsin memiliki tingkat kekebalan 100\%, sehingga tidak akan tertular alfasad. Hasil simulasi numerik dari skenario $\mathrm{C}$ ditunjukkan oleh Gambar 5.

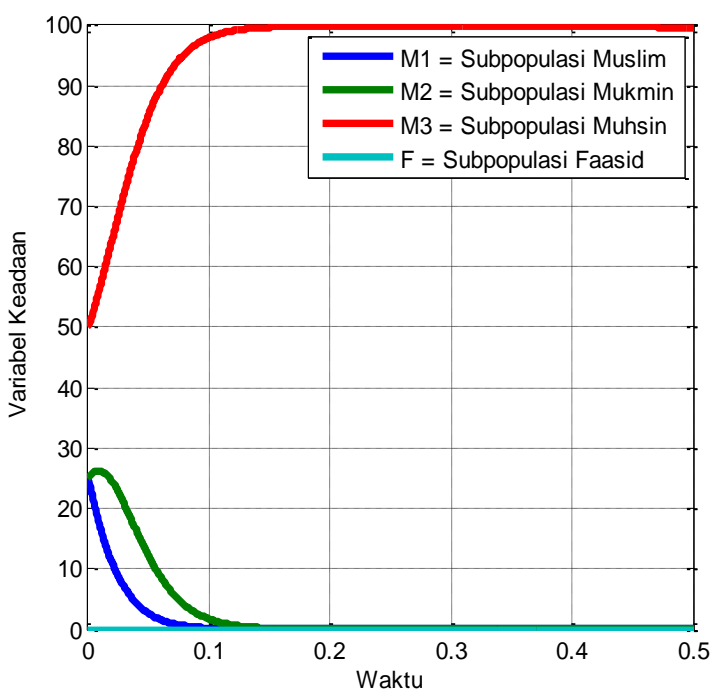

(a) Kondisi Awal $M_{1}: M_{2}: M_{3}: F=$ 25: 25: 50: 0

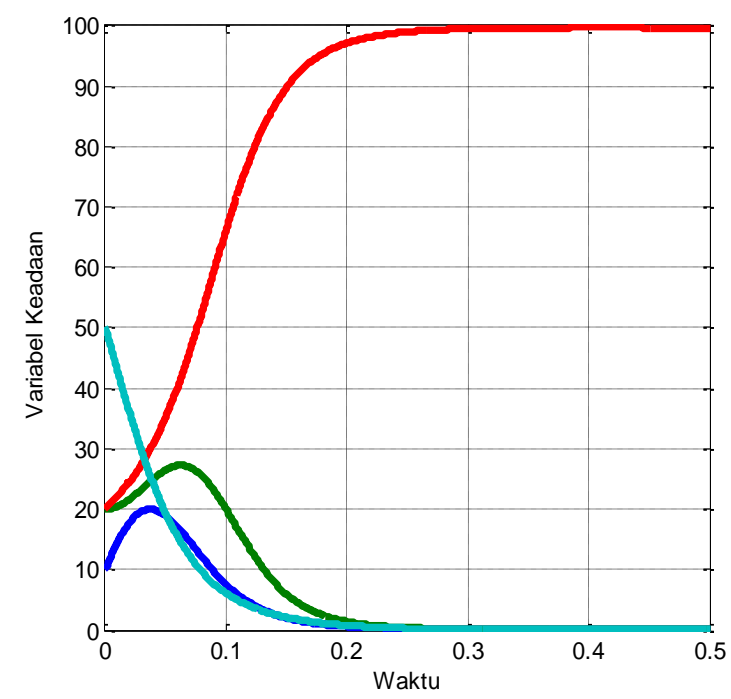

(c) Kondisi Awal $M_{1}: M_{2}: M_{3}: F=$ 10: 20: 20: 50

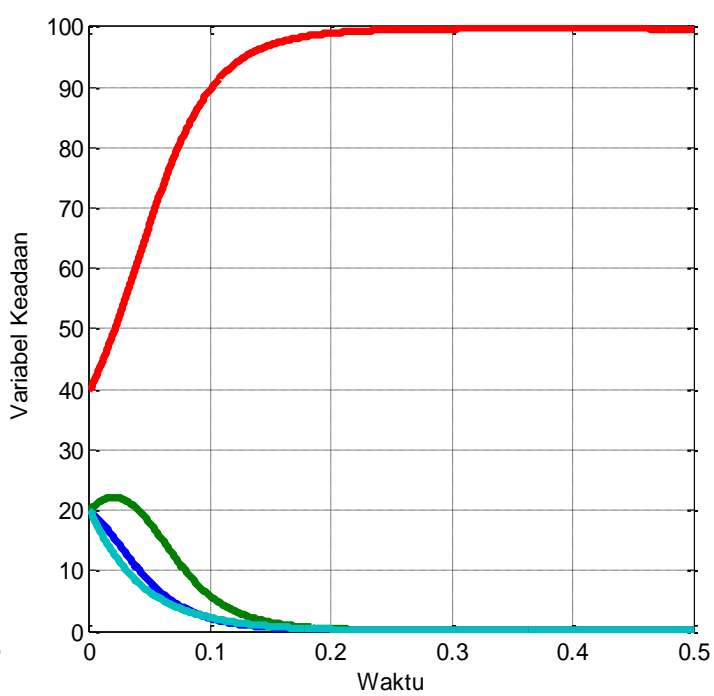

(b) Kondisi Awal $M_{1}: M_{2}: M_{3}: F=$ 20: $20: 40: 20$

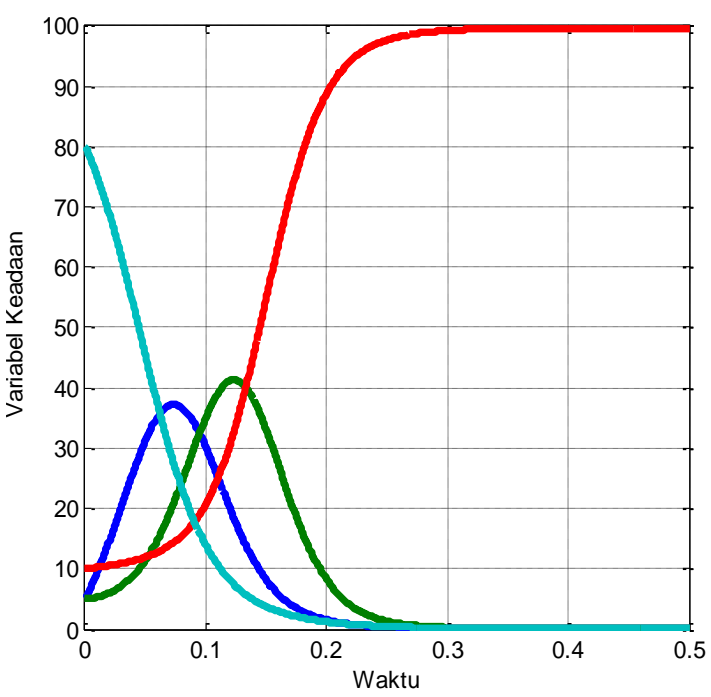

(d) Kondisi Awal $M_{1}: M_{2}: M_{3}: F=$ 5: 5: $10: 80$

Gambar 5. Dinamika Populasi Muslim-Mukmin-Muhsin-Faasid dalam Suatu Lingkungan dengan Tingkat Kerentanan 0\% Terhadap Al-Fasad

Simulasi numerik yang dihasilkan pada skenario $\mathrm{C}$, serupa dengan skenario A. Perbedaannya terletak pada waktu yang diperlukan oleh skenario A dan C dalam mencapai kondisi lingkungan 100\% Muhsin. Melalui perbandingan Gambar 3 dan 
Gambar 5, terutama kondisi c dan d, dapat dilihat bahwa waktu yang diperlukan oleh lingkungan dalam skenario C untuk mencapai kondisi 100\% Muhsin adalah lebih cepat daripada skenario A. Hal ini disebabkan tingkat kekebalan individu terhadap al-fasad dalam skenario $\mathrm{C}$ lebih tinggi daripada skenario A.

\section{E. Kesimpulan}

Berdasarkan hasil konstruksi model matematika pada bagian IV, disimpulkan bahwa penyebaran al-fasad dapat dinyatakan oleh sistem persamaan diferensial biasa. Hasil simulasi numerik dan interpretasi yang dilakukan menunjukkan bahwa suatu lingkungan yang memiliki tingkat kerentananyang tinggi terhadap al-fasad, memiliki kecenderungan untuk mengubah lingkungannya menjadi rusak secara keseluruhan. Begitu pula sebaliknya, tingkat kekebalan yang tinggi terhadap alfasad, memiliki kecenderungan untuk mengubah lingkungannya menjadi baik secara keseluruhan.

Penelitian ini tidak mempertimbangkan adanya subpopulasi Musyrik dan Kafir, serta tidak membedakan antara Munafiq, Fasiq, maupun Dzolim. Pencegahan dan pengendalian penyebaran dari al-fasad juga tidak dipertimbangkan dalam penelitian ini. Selain itu, dinamika sistem secara analitik juga tidak dibahas. Oleh karena itu, penelitian selanjutnya dapat dikembangkan pemodelan matematika tentang dinamika penularan al-fasad dengan lebih kompleks dan lebih representatif terhadap keadaan yang sesungguhnya.

\section{Daftar Pustaka}

Abu Ja'far Al-Thobari, Jami'ul Bayan fi Ta'wilil Qur'an, Muassasatur Risalah, $1420 \mathrm{H} / 2000 \mathrm{M}$.

Abu Sa'ud Al-'Amadi Muhammad bin Muhammad bin Mushthofa, Irsyadul Aql Ila Mazaya Al-Kitab Al-Karim, Daaru Ihyai Turots Al-'Arobi, Beirut.

Abul Fada' Isma'il bin 'Umar bin Katsir Al-Qurosyi Al-Bishri, Tafsirul Qur'an AlAdzim, Daaru Thoyyibah, 1420 H/1999 M.

Al-Qurthubi, Al-Jami' Li Ahkami al-Qur'an, Daarul Kutub Al Mishriah, Kairo, $1384 \mathrm{H} / 1963 \mathrm{M}$.

Al-Zamakhsyari, Al-Kasyaf 'An Haqoiqi Ghowamidlut Tanzil, Daarul Kitab Al'Arabi, Beirut, $1407 \mathrm{H}$.

CNN Indonesia, "Membandingkan Karhutla di Indonesia Pada 2015 dan 2019”, 18 September 2019, dikutip dari https://m.cnnindonesia.com/teknologi/ 20190918104533-199-431485/membandingkan-karhutla-di-indonesia-pada2015-dan-2019, diakses pada 2 Oktober 2019, 9:27. 
D.K. Chaturvedi, Modeling and Simulation of Systems Using MATLAB and Simulink, CRC Press, Florida, USA, 2010.

Fakhruddin Arrozi Khotiburroi, Al-Tafsir Al-Kabir, Daaru Ihyai Turots Al-'Arobi, Beirut, $1420 \mathrm{H}$.

Ibnu 'Asyur Al-Tunisi, At-Tahrir wa Tanwir, Addaar At-Tunisi, Tunis, 1984 M.

Jamaluddin bin Mandzur Al-Anshori, Lisanul Arab, Daaru Shodir, Beirut, 1414 H, Juz 3.

Jennifer Viegas, "Half of All Marine Life Lost in 40 Years: WWF Report", 10 September 2018, dikutip dari https://www.abc.net.au/news/science/2015-0916/half-marine-life-lost-in-40-years/6779912, diakses tanggal 8 Oktober 2019, 23:15.

Nashiruddin Abu Sa'id Abdullah bin "Umar bin Muhammad Asyairozi AlBaidlowi, Anwaru Tanzil wa Asroru Ta'wil, Daarut Turots Al'arobi, Beirut, $1418 \mathrm{H}$.

Rizki Akbar Hasan, "Menilik 7 Fakta Dampak Kebakaran Hutan Amazon, Seberapa Parah?", 31 Agustus 2019, dikutip dari https://m.liputan6.com/global/read/4051489/ menilik-7-fakta-dampakkebakaran-hutan-amazon-seberapa-parah, diakses pada 1 Oktober 2019, 08:19.

Subdirektorat Statistik Demografi Badan Pusat Statistik, Proyeksi Penduduk Indonesia 2010-2035, Badan Pusat Statistik, Jakarta, 2013.

W.O. Kermack \& A.G. Mckendrick, A Contribution of The Mathematical Theory of Epidemics, Proceedings of The Royal Society of London, Series A, London: The Royal Society, 1927. 